\title{
The Impact of Problem-Based Learning (PBL) on Student Achievement in Engineering Subject Material at Vocational College Kuantan, Pahang
}

\author{
Mohd Hasril Amiruddin ${ }^{1^{*}}$, Sri Sumarwati ${ }^{1}$, Kusnin Amat ${ }^{1}$ \\ ${ }^{1}$ Faculty of Technical and Vocational Education, \\ Universiti Tun Hussein Onn Malaysia, Johor, MALAYSIA \\ *Corresponding Author \\ DOI: https://doi.org/10.30880/ojtp.2021.06.01.001 \\ Received 08 July 2020; Accepted 30 November 2020; Available online 31 March 2021
}

\begin{abstract}
Problem-Based Learning (PBL) is a student-centered teaching approach. This study was conducted to identify the impact of Problem-Based Learning (PBL) on student achievement in engineering subject material at Vocational College Kuantan, Pahang. The study design used in this study was a quasi-experimental type involving two study groups namely the experimental group and control group. The experimental group in this study was referred to as the group exposed to the PBL teaching method. Whereas the control group is a group that uses traditional teaching strategies that use the standard (lecture) method commonly practiced, however, the content of teaching for the subject of engineering materials is the same as the experimental group. The respondents in this study were 30 students of 1st-semester Fabrication Welding Metal that selected using purposive sampling. To determine the level of student achievement, the researcher presents an achievement test for the subject of engineering materials. The results of this study were analyzed by independent t-test using Statistical Package for The Social Science (SPSS) version 21.0. This study found that student achievement in the experimental group was higher than the control group achievement. This shows that the PBL teaching method affects students' achievement in the subject of engineering materials at Vocational College Kuantan, Pahang. It is hoped that the findings of this study can serve as a reference to various stakeholders in designing and implementing problem-based learning methods to produce skilled thinkers who are critical in their work, problem-solving skills, and lifelong learning.
\end{abstract}

Keywords: Problem-Based Learning (PBL), teaching and learning

\section{Introduction}

Nowadays, technological developments, social and economic occurs very rapidly. At the same time, an individual has the desire to continuously develop the abilities and knowledge that they have in order to function to the maximum in daily life, work, and socialization in society. Thus, education and training can also help individuals to improve their lives by providing skills and knowledge to increase productivity in employment. Learning is a means of acquiring knowledge or skills through experience, a practice learned, or taught. Traditional learning as practiced by most students is passive learning. They spend most of their schooling in a passive learning environment by memorizing all the information that teachers give in lectures without student involvement and learning. Students listen to lectures and recall facts given by teachers. Therefore, this method is more about teacher-centered learning (Elizabeth \& Zulida, 2012).

There are many studies conducted in western countries that have shown that problem-based learning is an alternative way of providing students who can solve problems critically, prioritize learning and be active in the face of today's challenges. Problem-based learning can enhance students' knowledge, attitudes, and practices (Arman, 2018). 
One of the ways learning can provide students with the ability to solve problems critically, knowledgeable, active, and effective in today's world is a problem-based learning method that uses real-life problems as a starting point for learning (Phungsuk, Viriyavejakul \& Ratanaolarn, 2017).

Vocational College students consist of various courses. The vocational fields chosen by the students include Electrical, Electronics, Machinery Workshop, Metal Fabrication Welding, Automotive, Building Construction and Cooling, and Air Conditioning. The vocational education system is a flexible and responsible system because it can be adapted to the needs of employees and employers (Rahman et al., 2015). Therefore, the goal of these vocational or skills subjects is to produce students who are skilled in relevant and meaningful employment to enable them to get a job, start a business, or pursue higher education or training.

Welding is a permanent bonding process for metal and non-metallic materials using heat or pressure (Amiruddin \& Sumarwati, 2020). There are more than 50 types of the welding process, such as arc welding, oxygen fuel welding, resistance welding, friction welding, cold welding, and so on. Thus, knowing the engineering materials is a must-know basis to ensure that the materials to be used to meet the required features of each product and the product design to be produced. Current learning scenarios show that students cannot see the importance of the knowledge they have learned in class to their success in real life.

Traditional learning often causes learning to be superficial or inaccurate and students find learning content too abstract, boring, and difficult to relate to real-world problems (Gonzalez, 2018). Students' negative attitude towards this passive learning process can be seen through the decline in attendance and poor academic achievement (Bukoye \& Shegunshi, 2016). Problem-Based Learning (PBL) is a method of learning that uses real, relevant, meaningful problems as the focus of the learning process.

Problem-Based Learning can be adapted to the student's character, the learning environment, and the problems presented (Chung, Yeh \& Chen, 2016). The atmosphere of the PBL allows students to shape their ability to adapt to the given problem situation (Wijayati, Sumarni \& Supanti, 2019). Students have more opportunities to learn problemsolving processes related to various skills. PBL is rarely seen in everyday teaching and learning in schools while skills such as thinking, planning, communicating, and collaborating are very important in problem-solving, as well as teaching and learning processes. Scenarios in school emphasize the cognitive and not emphasize the skills that a student should have. Some people may find that PBL is more appropriate for more mature students at the university level and not at the school level. Therefore, this study aims to identify the impact of Problem-Based Learning (PBL) on student achievement in engineering subject material.

\section{Problem-Based Learning (PBL)}

Problem-Based Learning (PBL) is a student-centered teaching approach that allows students to master problemsolving processes, integrate theories and practices, and use knowledge and skills to build solutions in problem-solving (Marra et al., 2014). Through the PBL process, students need to interpret problems, gather information, identify possible solutions, evaluate each solution, and present all the conclusions and decisions made (Phungsuk, Viriyavejakul \& Ratanaolarn, 2017; Torp \& Sage, 2002). Gallow and Hewlett (2002) state that PBL is a process of teaching and learning based on student-centered. PBL is an approach that uses real-world cases or the beginning of a learning process through the problems they encounter (Barron \& Wells, 2013). The PBL also refers to the efforts shown by the student himself and the teacher only as a tutor or facilitator to help with a little bit of the matter to avoid any conflict. PBL is a learning environment that nurtures students to be self-sufficient, learn to gain knowledge, and be able to think globally but learn creativity (Bell, 2010).

According to Tan (2003), the PBL approach to teaching usually involves the following characteristics:

i. Problems are central to teaching.

ii. Problems are usually related to the actual situation.

iii. Problems will generate many perspectives and involve many topics.

iv. Problems that challenge students in terms of knowledge, attitudes, and competencies. PBL provides a new approach to learning situations.

v. Individual learning is important. Students are more responsible for the knowledge, and information gathered.

vi. Students utilize the various sources of knowledge, and this is indispensable in the PBL process.

vii. Students work together in a group and this trains students to interact, communicate, and collaborate.

viii. Improved investigation and troubleshooting techniques. It is important to solve the problem.

ix. The PBL process is terminated through synthesis and integration in teaching. PBL can also be concluded by evaluating and reviewing students' experiences and learning processes.

Through the learning techniques learned, students can become accustomed to learning something in a new setting (Mansor \& Madar, 2017). One of the features of this PBL is group discussion. Once students have read and understood the problem, they will have a small group discussion to come up with some ideas to solve the problem. At this level, students can formulate hypotheses based on problems and divide assignments accordingly. The research will be carried out continuously and systematically with planning in their respective groups. Nevertheless, meetings with other members of the group need to be held to understand the problems and developments of the research being conducted. Students will present their findings in front of the class to provide a lesson to share. At this point, the lecturer should 
assist the student in the event of any misunderstandings. This is to ensure that students do not get the wrong information. The results should be evaluated by the lecturer and should be supplemented if necessary.

PBL strategies are ways of teaching based on scientific investigations. The purpose of problem-solving is to provide students with the opportunity to apply the concepts, principles, and theories that have been learned. It also encourage critical, analytical, logical and rational thinking, reinforce the principles and theories that have been learned, enhance and reinforce students' memory, meet the needs of the learning by doing' principles, satisfy students to achieve the desired result, build confidence among students and foster self-development. According to Hmelo-Silver (2004), there are three phases in solving problems:

(i) The problem understanding phase

a. Understand the problem by making sure all definitions and meanings are known.

b. Rewrite relevant facts and information.

c. List all the information provided and create another list of unknown information.

d. Formulate such information in mathematical or graphical terms such as diagrams, graphs, diagrams, charts, etc.

(ii) The determination method phase

a. Use past solution experiences to observe similarities in terms of existing information.

b. If there are no similarities, try to solve them using basic principles, logical arguments, or try and wrong methods.

c. If these steps do not produce a response, look back at the information to redefine the problem to be solved by different approaches.

(iii) The problem formulation phase

a. After getting an answer, formulate a solution so that it can be an experience and example to solve similar questions in the future.

According to Md Zabit (2010), one of the main advantages of PBL over other learning strategies suggested by the theory of constructivism is the stimulation has produced in shaping students' cognitive curiosity. This is because they succeed in enhancing the students' motivation or motivation to continue learning. Problems that resemble real-world problems are used to enable students to try various solutions in a safer learning environment (Mohd. Yusof et al., 2005).

\section{Methodology}

The study design used in this study was a quasi-experimental study. This study involved two research groups namely the experimental and control group. The respondents in this study were 30 students of 1st-semester Fabrication Welding Metal that was selected using purposive sampling. Since the 1st-semester students of Fabrication Welding Metal at Vocational College Kuantan, Pahang are all male, then all the respondents of this study are male students. A total number of 30 students were selected as study respondents namely 15 students from the experimental group and 15 students from the control group. The respondents for the experimental and control groups in this study were the same and there were no differences among students (Levene test, $\mathrm{p}=0.58$ ).

Table 1 - Analysis of respondents' profiles by gender

\begin{tabular}{llccc}
\hline \multirow{2}{*}{ Analysis of respondents' profiles by gender } & \multicolumn{2}{c}{ Research Group } & \multirow{2}{*}{ Total } \\
\cline { 3 - 4 } & Male & Experimental & Control & \\
\hline \multirow{2}{*}{ Gender } & Mannnnnn & 15 & 15 & 30 \\
& Female & 0 & 0 & 0 \\
\hline Total & & 15 & 15 & 30 \\
\hline
\end{tabular}

Mauldin and Decarlo (2020) explained that the experimental group was the treatment group (stimulus) and the group that received the effect of the dependent variable, while the control group was the group that did not receive treatment (stimulus) in the study. The experimental group in this study is referred to as the PBL group which is the experimental group exposed to the teaching of engineering materials through Problem-Based Learning (PBL) strategies. While the control group is referred to as traditional teaching, that is, the group that goes through the traditional teaching strategy by using the method of explanation (lecture) that is commonly practiced. Nevertheless, the teaching content between the experimental and control groups was similar.

To determine the level of student achievement, the researcher provided a test of achievement for the subject of engineering materials after the PBL teaching method was implemented in the experimental group and the control group using the traditional teaching method. This research instrument is a set of achievement test questions in the subject of engineering materials prepared by a lecturer of the Vocational College Kuantan, Pahang who has more than 15 years of teaching experience. Table 2 shows the achievement test questions consisting of 18 items, in which respondents were given time to answer for one hour fifteen minutes. The reliability of this study instrument was 0.892 . Therefore, the instruments of this study are reliable and suitable for obtaining stable test results from the respondents of the study. 
Table 2 - The achievement test

\begin{tabular}{ccc}
\hline Part & Question & Marks \\
\hline & 1 & 5 \\
2 & 5 \\
& 3 & 4 \\
& 4 & 5 \\
& 5 & 4 \\
& 6 & 5 \\
& 7 & 4 \\
& 8 & 5 \\
& 9 & 5 \\
& 10 & 4 \\
& 11 & 5 \\
& 12 & 4 \\
& 13 & 5 \\
& 14 & 5 \\
& 15 & 5 \\
\hline \multirow{2}{*}{ B } & 1 & 10 \\
& 2 & 10 \\
\hline TOTAL & 3 & 10 \\
\hline
\end{tabular}

The results of this study were analyzed using descriptive statistics of mean, standard deviation, and independent ttest. The independent t-test is used to analyze the data to identify whether there are differences or not, related to the level of achievement between groups of students exposed to the Problem-Based Learning (PBL) method and students exposed to the traditional teaching strategies. The findings of this study were analyzed using the Statistical Package for The Social Science (SPSS) version 21.0.

\section{Finding and Discussion}

This study found that semester 1 student of metal fabrication welding involved in the experimental group felt that they were prepared to study through the Problem-Based Learning (PBL) method. The results show that students' commitment to the preparation of learning in the PBL is very high. From the study, the respondents agreed that they are willing to learn PBL through a variety of creative ideas. One of the important points of generating creative ideas in learning is ensuring that students have a variety of solutions to their problems. It is also supported by Ulger (2018), that students can think creatively in solving problems related to a real event.

Once students can come up with creative ideas, they need to train themselves to get the information. One way to find information through reading. Students need to read topics related to the topic of the problem so that they can describe the situation to be studied. Once the real picture is obtained, then the issue can be generated. It is agreed by Tan (2003), that students generate ideas on how to solve problems and then decide on topics to enable them to decide the issues they want. Instead, students can see how important they are to train themselves to generate more creative ideas.

Table 3 shows that there is a difference in mean values for achievement tests conducted on students in the experimental and control groups. The findings of this study found that the mean test score for the experimental group was $80.20(\mathrm{SD}=8.13458)$, while the mean value of the control group was $72.40(\mathrm{SD}=8.05162)$. The mean difference between the experimental and control groups was 7.80 .

Table 3 - Mean and standard deviation of achievement test for experimental and control groups

\begin{tabular}{lcc}
\hline \multicolumn{1}{c}{ Group } & Mean & Standard Deviation (SD) \\
\hline Experimental Group & 80.20 & 8.13458 \\
Control Group & 72.40 & 8.05162 \\
\hline
\end{tabular}

Based on the results of the analysis shown in Table 4, it was found that the Levene's Test $(p=0.58)$ was greater than the $\alpha=0.05$ value. This indicates that the variants for the experimental and control groups are the same. The analysis using the t-test found that the difference in achievement level between the experimental and control group students was significant $(\mathrm{p}=0.001)$ or smaller than 0.05 , so the null hypothesis was rejected. Therefore, there are differences in achievement levels between groups of students exposed to Problem-Based Learning (PBL) methods and those using traditional teaching strategies. This study found that student achievement in the experimental group was 
higher than the control group. The findings of this study support the results of Mokter (2019) study that found that the achievement level of students using the PBL approach is higher than that of students using traditional teaching and learning methods.

Table 4 - Independent t-test

\begin{tabular}{lccccccc}
\hline Group & $N$ & Mean & $\begin{array}{c}\text { Levene's Test for } \\
\text { Equality of Variances }\end{array}$ & & \multicolumn{2}{c}{ t-test for Equality of Means } \\
\cline { 3 - 7 } & & & Sig. & $t$ & $d f$ & Sig. (2-tailed) & Mean Difference \\
\hline Experimental & 15 & 80.20 & 0.58 & 1.214 & 28 & 0.001 & 7.80 \\
Control & 15 & 72.40 & & & & & \\
\hline
\end{tabular}

The significant level of 0.05

Based on the findings in this study, the PBL teaching method affects students' achievement in the subject of engineering materials at Vocational College Kuantan, Pahang. The actual process of PBL starts with identifying problems, generalizing ideas and facts, learning issues, self-learning, applications and synthesis, reflection, feedback, and finally finding solutions to problems. PBL requires students to be more active in collecting the information they need. Students can not only remember facts and theories, but they can apply them in the real world. They can also appreciate the responsibility they have for developing their learning style. As Macdonald and Savin-Baden (2004) point out, students can see, remember, and understand the theory gained.

\section{Conclusion}

The process of learning and teaching at the Problem-Based Learning (PBL) is more realistic in the world of education where students can solve problems that arise, and students can develop their thinking towards more creative and critical thinking as well as the complexity of the problems that drive the learning process. This method of learning helps students to become more engaged in learning the process of success and not just rely on the lecturer. The findings of this study found that the achievement of students exposed to PBL teaching methods was higher than that of students exposed to traditional teaching methods. Therefore, it can be concluded that the PBL method has a positive impact on students' achievement. However, the role of the lecturer is very necessary for the success of this PBL method. When students encounter problems throughout learning, they want to identify the problem in detail and find out the explanation from the lecturer. Lecturers should pay attention to what students are learning naturally, not only commenting on the quality of the research and synthesis but also providing guidance on the synthesis they are doing right or wrong. It can be concluded that the findings of this study show a positive result on the role of PBL in improving student achievement. Therefore, this Problem-Based Learning (PBL) method can be applied by other lecturers to improve the quality of student achievement in general.

\section{Acknowledgement} K011.

The authors would like to thank the Ministry of Education Malaysia for supporting this research through PPG VOT

\section{References}

Amiruddin, M. H. \& Sumarwati, S. (2020). The Distance Monitoring Tools between the Ends of the Nozzle with the Workpiece for Gas Metal Arc Welding. International Journal of Engineering and Advanced Technology (IJEAT), 9 (3): 2880-2885

Arman, A. M. (2018). Students' Attitudes toward Problem Based Learning - Analog Electronic Course in the Electrical Engineering Programs in PPU Case Study. Journal of e-Learning and Higher Education

Barron, L., \& Wells, L. (2013). Transitioning to the Real World through Problem-Based Learning: A Collaborative Approach to Teacher Preparation. Journal of Learning in Higher Education, 9 (2)

Bell, S. (2010). Project-Based Learning for the 21st Century: Skills for the Future. The Clearing House, 83: 39-43

Bukoye, O. T., \& Shegunshi, A. (2016). Impact of engaging teaching model (ETM) on students' attendance. Journal Cogent Education, 3, 1 
Chung, P., Yeh, R.C. \& Chen, YC. (2016). Influence of problem-based learning strategy on enhancing student's industrial oriented competences learned: an action research on learning weblog analysis.

International Journal of Technology and Design Education, 26: 285-307

Elizabeth, M. A., \& Zulida, A. K (2012). Problem-Based Learning: A Source of Learning Opportunities in Undergraduate English for Specific Purposes. The International Journal of Social Science, 3, 1

Gonzalez, A. (2018). Turning a traditional teaching setting into a feedback-rich environment. International Journal Education Technology Higher Education, 15, 32

Hmelo-Silver, C.E. (2004). Problem-Based Learning: What and How Do Students Learn? Educational Psychology Review 16, 235-266

Macdonald, R. F., \& Savin-Baden, M. (2004). A Briefing on Assessment in Problem-based Learning. LTSN Generic Centre Assessment Series. Available on the Higher Education Academy's Resource Database at: www.heacademy.ac.uk/resources.asp?process=full_record\&section=generic\&id=349

Mansor, M., \& Madar, A. R. (2017). Product-orientated learning efficacy among technical students. Pertanika Journal of Social Sciences and Humanities

Mauldin, R. L. \& Decarlo, M. (2020). Guidebook for Social Work Literature Reviews and Research Questions. Mavs Open Press at UT Arlington

Marra, R., Jonassen, D. H., Palmer, B., \& Luft, S. (2014). Why problem-based learning works: Theoretical foundations. Journal on Excellence in College Teaching, 25, 221-238

Md Zabit, M. N. (2010). Problem-Based Learning on Students Critical Thinking Skills in Teaching Business Education in Malaysia: A Literature Review. American Journal of Business Education (AJBE), 3

Mohd-Yusof, K., Tasir, Z., Harun, J., \& Helmi, S. (2005). Promoting Problem-Based Learning (PBL) in Engineering Courses at the Universiti Teknologi Malaysia. Global Journal of Engineering Education, 9: 175-184

Mokter, F.A. (2019). The Effectiveness of Problem Based Learning on Achievement and Students Higher Order Thinking Skills in Malay Language Essay Writing. Malay Language Education Journal, 9 (1): 33-46

Phungsuk, R., Viriyavejakul, C. \& Ratanaolarn, T. (2017). Development of a problem-based learning model via a virtual learning environment. Kasetsart Journal of Social Sciences, 38, 3: 297-306

Rahman, S. H. A., Jusoh, Z. Y. M., Serji, R. M. \& Salleh, M. (2015). Faktor-faktor Kepuasan Majikan Terhadap Pelajar Latihan Industri di Institut Pengajian Tinggi (IPT): Satu Sorotan. E-Proceeding of the 2nd International Conference on Arabic Studies and Islamic Civilization, iCASiC2015 (e-ISBN 978-967-0792-02-6), 9-10 March 2015, Kuala Lumpur, MALAYSIA

Tan, O. S. (2003). Problem-based learning innovation: Using problems to power learning in the 21 st century. Singapore: Thomson Learning

Torp, L., \& Sage, S. (2002). Problems as Possibilities: Problem-Based Learning for K-12Education, 2nd edn., ASCD, Alexandria, VA

Ulger, K. (2018). The Effect of Problem-Based Learning on the Creative Thinking and Critical Thinking Disposition of Students in Visual Arts Education. Interdisciplinary Journal of Problem-Based Learning, 12 